\title{
How to Improve Image Quality for the Chest PA and the Simple Abdomen $\mathrm{X}$-ray Examinations
}

\author{
Pyong Kon Cho \\ Department of Radiological Science, Catholic University of Daegu \\ 흥, 복부 단순 $\mathrm{X}-\mathrm{ray}$ 검사 시 영상의 질 향상 방법 \\ 조평곤 \\ 대구가톨릭대학교 방사선학과
}

\begin{abstract}
The purpose of this study is to examine how much the movement at X-ray examinations like breathing or the positioning affects the image during chest or abdomen X-ray examination so as to create an image containing information as much as possible. The study method adopted is doing the X-ray in each of the states including breathing (inspiration \& expiration) and movement in the standing chest PA X-ray and simple abdomen X-ray among the kinds of examination selected the most in hospitals and then evaluating them by applying the standards of image evaluation for each region. According to the study result, about the standing chest PA X-ray, the images taken at inspiration contain more information than those taken at expiration or having subtle movement during the examination. About the simple abdomen X-ray, the images taken at expiration contain more information than those taken at inspiration or movement. The above study results imply that regarding general X-ray examination, information we can find from the images may differ significantly according to the region examined, examination purpose, or movement during the examination like breathing.
\end{abstract}

Key words: Chast PA, Simple Abdomen X-ray, inspiration, expiration, image quality

\section{요야}

이 연구의 목적은 흉부, 복부 $\mathrm{X}$ 선 검사 시 호흡, 위치 잡이, 촬영 중 움직임 등이 있을 때 영상에 어느 정도의 영향 이 있는지를 알아보고 가능한 많은 양의 정보를 포함하고 있는 영상을 만들기 위함이다. 연구방법은 병원에서 가장 많 이 촬영되어지고 있는 검사 중 선 자세 흉부 후전방향 $\mathrm{X}$ 선 검사 와 누운 자세 복부 전후방향 $\mathrm{X}$ 선 검사에서 호흡을 들 이 마신상태, 내 쉰 상태, 움직임이 있는 상태에서 각 각 $\mathrm{X}$ 선 촬영을 한 후 각 부위 별 영상평가기준을 적용하여 평가 하였다. 연구 결과 선 자세 흥부 후전방향 X선 검사는 숨을 내 쉰 상태, 조사 중 미세한 움직임이 있는 경우 보다 숨을 들이 마신상태에서 촬영한 영상에서 가장 많은 정보가 포함되어있는 것을 확인 할 수 있었다. 누운 자세 복부 전후방 향 $\mathrm{X}$ 선 검사는 숨을 들이 마신상태, 움직임이 있는 경우 보다 숨을 내 쉰 상태 에서 촬영한 영상에서 가장 많은 정보가 포함되어있는 것을 알 수 있었다. 이와 같은 연구결과에서와 같이 일반 $\mathrm{X}$ 선 검사의 경우 검사부위, 검사목적에 따라서 호흡 또는 검사 중 움직임 등에 따라 영상에서 발견할 수 있는 정보에 많은 차이가 있음을 알 수 있었다

중심단어: 흉부 X선 검사, 복부 X선 검사, 숨을 들이 마신 상태, 숨을 내 쉰 상태, 영상의 품질 


\section{I. 서론}

방사선은 우주가 생겨날 때부터 존재하였으며 지구 의 역사와 함께 존재하여 왔고 현재에도 공기나 물과 같이 환경을 구성하고 있는 수많은 필수요건 중의 하 나로 앞으로도 계속 우리와 더불어 존재할 것이다. 이 와 같이 인간의 생활에 직, 간접적으로 영향을 미치는 방사선에는 자연 방사선과 인공방사선으로 구분할 수 있다. 자연방사선에는 우주선(cosmic rays), 지각방사선 (radiation from soil and rocks), 라돈과 라돈자손(radon and its progeny), 인체내부의 자연방사선 등이 있으며, 인공방사선으로는 의료 방사선, 방사선낙진(fall out) 원 자력 시설에서의 방사선 등이 있다 ${ }^{[1]}$. 인류는 끊임없이 자연방사선 피폭을 받고 있으며, 또 한편으로는 인간, 그리고 인간사회는 여러 가지 형태로서 방사선을 이용 해서 이익을 얻고 있다. 그러나 방사선은 인류에게 항 상 이익만 주는 것은 아니다. 방사선은 그 특성에 의해 장해의 부담을 주게 되는데 방사선 장해의 위험성이 문제가 되기 시작한 것은 인공 방사선을 적극적으로 이용하기 시작하면서부터이다. 방사선을 사용하는 경 우 허용된 범위의 피폭이라 하더라도 방사선피폭으로 인한 이익이 손실보다 클 경우에만 피폭을 허용하며, 가능한 방사선 피폭을 줄임으로서 방사선 피폭으로 인 한 확률적 영향과 비확률적 영향의 발생을 감소시킬 수 있다. 보고된 자료에 의하면 인공방사선에 의한 피 폭 중 가장 많은 영역을 차지하고 있는 것이 의료방사 선에 의한 피폭이다 ${ }^{[2]}$. 그 중 흉부, 복부 $\mathrm{X}$ 선 검사는 병 - 의원에서 실시하는 검사 중에서도 단연 가장 높은 빈도를 가지고 있다. 흉부X선 사진은 다른 부위의 사진 들보다도 해부, 병리학적으로 많은 진단적 정보를 포함 하고 있으며 실제로 훙부는 방사선 투과성이 매우 높 은 폐와 낮은 종격동 및 골성 흥곽조직이 함께 위치해 있어 X선으로 검사될 수 있는 가장 복잡한 부위이다[3]. 흉부X선 촬영이 이러한 중요한 위치에 있음에도 불구 하고 통상적 검사(routine study)의 한 단계로서의 일반 성 때문에 촬영과정이 신중이 다루어지지 않았던 일면 이 있는 것이 사실이다. 한편, 복부 $\mathrm{X}$ 선 검사의 경우 방사선 투과성이 비슷한 기관들로 구성 되어있고 복강 내 장기들의 움직임에 의한 불선예도 방지 등 가능한 많은 정보가 들어있는 영상을 만들어줄 수 있도록 해
야 한다.

본 연구는 흥부, 복부 $\mathrm{X}$ 선 검사 시 호흡, 위치 잡이 의 중요성, 촬영 중 움직임 등이 있을 때 영상에 어느 정도의 영향이 있는지를 알아보고 가능한 많은 양의 정보를 포함하고 있는 영상을 만들기 위해 연구되었다.

\section{II. 연구대상 및 방법}

\section{1. 연구대상}

건강검진 등을 통해 흉부와 복부 $\mathrm{X}$ 선 검사에서 그 동안 특별한 질병이 발견되지 않은 8명(남: 2 명, 여: 6 명, 나이: 20세 - 25세)을 대상으로 하였고, 모든 연구 참여 대상자로부터 연구 참여에 대한 동의를 받은 후 2011년 11월 과 12월 사이 일반촬영용 X선 촬영장치 (REX-525R, LISTEM, KOREA), CR reader(CR30-X, AGFA, GERMANY)를 이용하여 시행 하였다.

\section{2. 선 자세 흥부 후전방향 $\mathrm{X}$ 선 검사 \\ (Chest PA X-ray Examinations)}

선 자세 흥부 후전방향 $\mathrm{X}$ 선 검사의 위치 잡이는 체 중을 양쪽 발에 균일하게 분포 시킨 후 턱은 수직 격자 장치(wall burky)의 위 부분 중앙에 올려놓게 하고, 양 손은 양 쪽 대퇴골의 대전자(greater trochanter) 부위에 놓고, 손바닥은 몸의 바깥쪽으로 향하게 위치 잡이 한 다. 양쪽 어깨(shoulder region)는 어깨뼈가 흥부 바깥쪽 으로 이동 되도록 수직격자장치 앞쪽으로 회전시킨다. 또한, 양쪽 어깨는 양쪽 빗장뼈(쇄골, clavicle)가 허파꼭 대기부(폐첨부, apices) 아래로 이동되도록 충분히 내려 수직격자장치에 밀착시킨다. 몸의 정중면(midsagittal plane)을 카세트(cassette or image plate; IP)의 중앙선에 일치시켜 흉부가 회전되지 않도록 확인한다. 일곱째 등 뼈(흥추골, thoracic vertebra) 높이의 정중면에 중심X선 을 IP에 수직으로 입사한다. 중심X선에 IP의 중앙을 맞 추고 $\mathrm{X}$ 선관 초점-영상면 사이 거리(source image distance; SID)는 $180 \mathrm{~cm}$ 로 조정한다. 조사야(collimator) 는 폐야(lung field) 전체가 포함 되도록 조사야를 조절 한다. IP의 위쪽 부는 솟을뼈(융추, vertebra prominens, 일곱째 목뼈)의 높이가 되도록 하며 옆쪽 부는 흥부 가 쪽이 포함 되게 조절한다. 이와 같이 위치 잡이를 한 
후 X선의 조사는 숨을 들이 마신 후(inspiration), 숨을 내 쉰 후(expiration), 숨을 들이 마신 상태에서 훙부가 미세하게 움직인 상태에서 조사 되었다(Fig. 1) ${ }^{[4]}$. 선 자 세 흉부 후전방향 X선 검사 시 심장, 대동맥, 척추 등 의 뼈, 여성의 큰 유방, 횡격막 하의 장기 등의 영역과 쇄골이나 폐문부의 복잡한 혈관, 기관지 등에 중복 투 영되는 부위에서는 X선 흡수가 커 폐야보다 저농도, 저 대조도 부분으로 나타나며 병변 발견이 곤란하기 때문 에 더 많은 정보를 관찰하기 위하여 고관전압 촬영 방 법인 관전압 $120 \mathrm{kVp}$, 관전류 $200 \mathrm{~mA}$, 조사시간 0.01 $\sim 0.02 \mathrm{sec}$ 를 이용해 검사 하였다.

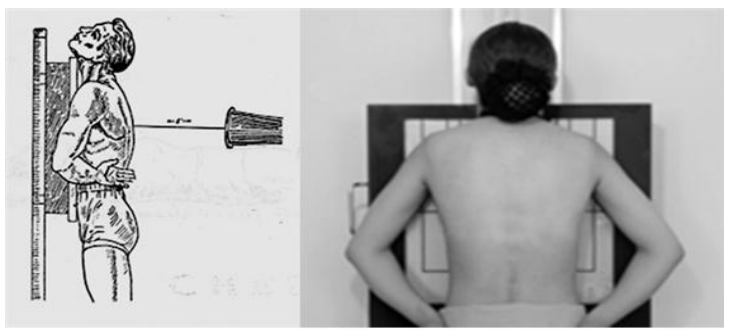

Fig. 1. Radiographic position for the Chest PA X-ray examinations

\section{3. 누운 자세 복부 전후방향 $\mathrm{X}$ 선 검사 \\ (Supine abdomen AP X-ray Examinations)}

누운 자세 복부 전후방향 X-ray 검사 시 위치 잡이는 촬영대 위에 편안한 자세로 조정하고 머리 밑에 베개 와 무릎아래 지지물을 놓아 긴장을 완화시킨다. IP의 중앙선과 촬영대의 중앙선이 일치하도록 하고, $\mathrm{IP}$ 의 중 앙선에 정중면을 맞춘다. 양쪽 골반부가 균형이 되게 놓이도록 하며 양 팔은 머리 위 또는 배옆(측복부)에 닿지 않도록 양 옆에 놓는다. 호흡은 방사선 촬영의 중 요한 인자로써, 영상에서 호흡에 의한 움직임의 영향을 최소화 할 수 있도록 가능한 X선 조사시간을 짧게 선 정하는 것이 불수의적인 움직임을 방지하는데 좋다. 또 한 수의적인 움직임을 예방하는 방법은 조심스러운 호 흡훈련을 통하여 X선 조사 중 호흡을 정지시키는 것이 다. 본 연구에서는 호흡의 변화에 대한 복강 내 장기의 움직임 등을 관찰하기 위하여 숨을 들이 마신 후 (inspiration), 숨을 내 쉰 후(expiration), 숨을 쉰 상태에서 복부가 미세하게 움직인 상태에서 조사 되었다(Fig.
2) ${ }^{[5]}$. 조사야는 일반적으로 해부학적 구조가 충분히 보 이도록 하며, 환자의 정보표시(identification) 등은 읽기 쉽도록 명확해야 하고, 좌우 및 위, 아래 표지를 하고 배 구조들과 겹치지 않도록 한다. 특히, 누운 자세 복부 전후 방향 X-ray 검사에서는 생식기에 대한 방사선 피 폭을 감소시키기 위하여 생식샘 보호 기구를 이용하여 생식기에 대한 차폐를 실시해야 한다. 누운 자세 복부 전후방향 $\mathrm{X}$ 선 검사 시 촬영 조건은 허리근(요근, psoasmuscle), 간 아랫부(liver lower margin), 콩팥(신장, kidneys), 허리뼈(요추, lumbar spine)의 가로돌기(횡돌기, transverse process)가 나타나야 하며, 다양한 배 구조, 콩 팥(신장) 또는 쓸개(담낭)내 작은 담석들을 나타내야 하 기 때문에 관전압 $72 \mathrm{kVp}$, 관전류 $200 \mathrm{~mA}$, 조사시간 $0.1 \sim 0.16 \mathrm{sec}$ 를 이용해 검사 하였다.

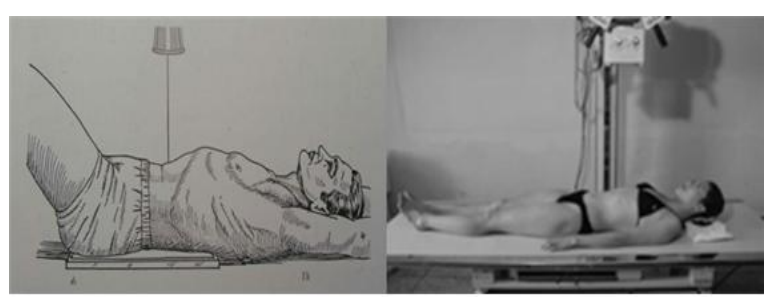

Fig. 2. Radiographic position for the supine abdomen AP X-ray examinations

\section{4. 선 자세 흥부 후전방향 $\mathrm{X}$ 선 영상평가}

선 자세 흉부 후전방향 X선 영상평가는 호흡의 변화 에 따라 촬영 된 각 각의 영상을 $\mathrm{CR}$ reader로 읽은 후 영상을 “JPEG"로 변환 시켜서 일반 개인용 컴퓨터 모 니터를 이용해 평가하였다. 평가항목은 일반적으로 선 자세 흥부 후전방향 X선 영상 평가 시 많이 이용하는 항목(Table 1)에 대해서 “매우 그렇다, 그렇다, 보통이 다, 그렇지 않다, 매우 그렇지 않다.” 로 평가하였다.

\section{5. 누운 자세 복부 전후방향 $\mathrm{X}$ 선 영상평가}

누운 자세 복부 전후방향 X선 영상평가는 호흡의 변화에 따라 촬영 된 각 각의 촬영 된 영상을 $\mathrm{CR}$ reader 로 읽은 후 영상을 “JPEG"로 변환 시켜서 일반 개인용 컴퓨터 모니터를 이용해 평가하였다. 평가항목은 일반 적으로 누운 자세 복부 전후방향 X선 영상 평가 시 많 이 이용하는 항목(Table 2)에 대해서 "매우 그렇다, 그 
렇다, 보통이다, 그렇지 않다, 매우 그렇지 않다.” 로 평 가하였다.

Table 1. Evaluation list for the Chest PA X-ray image

\begin{tabular}{|l|}
\hline \multicolumn{1}{|c|}{ 평 가 항 목 } \\
\hline 견갑골은 가능한 한 폐야 밖으로 제거되어 있는가? \\
\hline 흥곽은 충분히 확장되어 있는가? \\
\hline 영상의 대조도와 밀도는 충분한가? \\
\hline 심장, 빼, 횡격막, 폐의 marking은 선명한가? \\
\hline 골성흉곽과 폐경계가 뚜렷한가? \\
\hline 심장과 종격동에 의한 음영이 있는가? \\
\hline ㄴung marking이 심장 뒤쪽으로 보이는가? \\
\hline 페문음영은 한 덩어리로 되지 않고 판독하기 쉬운가? \\
\hline 흉추의 추간판공간이 미세하게 보이는가? \\
\hline 기관과 좌우기관지의 투과상이 보이는가? \\
\hline 좌하행대동맥이 보이는가? \\
\hline 심장과 횡격막으로 겹쳐진 폐혈관이 보이는가? \\
\hline 종격구조의 주행이 보이는가? \\
\hline 좌측 횡격막 하부에 공기로 차있는 위장의 음영이 보이는가? \\
\hline 우측 횡격막 하부에 간에 의한 음영이 보이는가? \\
\hline
\end{tabular}

Table 2. Evaluation list for the supine abdomen AP X-ray examinations

\begin{tabular}{|l|}
\hline \multicolumn{1}{|c|}{ 평 가 항 목 } \\
\hline 복강내 장기의 전반적인 윤곽 구분이 되는가? \\
\hline 영상의 대조도는 선명한가? \\
\hline 장요근이 보이는가? \\
\hline 가스 음영이 식별되는가? \\
\hline 간, 콩팥의 윤곽을 식별할 수 있는가? \\
\hline 외복벽과 복막의 지방층이 보이는가? \\
\hline 이에의 주행을 확인할 수 있는가? \\
\hline 전체적인 장내의 가스분포를 파악할 수 있는가? \\
\hline 척추 및 횡돌기의 윤곽이 잘 보이는가? \\
\hline 복강내 장기의 겹침을 확인할 수 있는가? \\
\hline
\end{tabular}

\section{1. 선 자세 흉부 후전 방향 $\mathrm{X}$ 선 검사 영상(Fig. 3) 평가 결과}

\section{1) 숨을 들이 마신 후(inspiration) X선을 조사시킨 영상}

견갑골은 가능한 한 폐야 밖으로 제거되어 있는가? 에 대해서 매우 그렇다 $37.5 \%$, 그렇다 $62.5 \%$, 보통이다 $0 \%$ 그렇지 않다. $0 \%$, 매우 그렇지 않다. $0 \%$ 이었다.

흥곽은 충분히 확장되어 있는가? 에 대해서 매우 그 렇다 $37.5 \%$, 그렇다 $50 \%$, 보통이다 $12.5 \%$ 그렇지 않다 $0 \%$, 매우 그렇지 않다. $0 \%$ 이었다.

영상의 대조도와 밀도는 충분한가? 에 대해서 매우 그렇다 $37.5 \%$, 그렇다 $62.5 \%$, 보통이다 $0 \%$ 그렇지 않다 $0 \%$, 매우 그렇지 않다. $0 \%$ 이었다.

심장, 뼈, 횡격막, 폐의 marking은 선명한가? 에 대해 서 매우 그렇다 $37.5 \%$, 그렇다 $50 \%$, 보통이다 $0 \%$ 그렇 지 않다. $12.5 \%$, 매우 그렇지 않다. $0 \%$ 이었다.

골성흉곽과 폐경계가 뚜렷한가? 에 대해서 매우 그 렇다 $25 \%$, 그렇다 $25 \%$, 보통이다 $37.5 \%$ 그렇지 않 다. $12.5 \%$, 매우 그렇지 않다. $0 \%$ 이었다.

심장과 종격동에 의한 음영이 있는가? 에 대해서 매 우 그렇다 $0 \%$, 그렇다 $37.5 \%$, 보통이다 $50 \%$ 그렇지 않 다. $12.5 \%$, 매우 그렇지 않다. $0 \%$ 이었다.

Lung marking이 심장 뒤쪽으로 보이는가? 에 대해서 매우 그렇다 $0 \%$, 그렇다 $37.5 \%$, 보통이다 $50 \%$ 그렇지 않다. $12.5 \%$, 매우 그렇지 않다. $0 \%$ 이었다.

페문음영은 한 덩어리로 되지 않고 판독하기 쉬운가? 에 대해서 매우 그렇다 $25 \%$, 그렇다 $12.5 \%$, 보통이다 $37.5 \%$ 그렇지 않다. $25 \%$, 매우 그렇지 않다. $0 \%$ 이었다.

흥추의 추간판공간이 미세하게 보이는가? 에 대해서 매우 그렇다 $0 \%$, 그렇다 $62.5 \%$, 보통이다 $37.5 \%$ 그렇지 않다. $0 \%$, 매우 그렇지 않다. $0 \%$ 이었다.

기관과 좌우기관지의 투과상이 보이는가? 에 대해서 매우 그렇다 $12.5 \%$, 그렇다 $25 \%$, 보통이다 $63.5 \%$ 그렇 
지 않다. $0 \%$, 매우 그렇지 않다. $0 \%$ 이었다.

좌하행대동맥이 보이는가? 에 대해서 매우 그렇다 $25 \%$, 그렇다 $12.5 \%$, 보통이다 $37.5 \%$ 그렇지 않다. $25 \%$, 매우 그렇지 않다. $0 \%$ 이었다.

심장과 횡격막으로 겹쳐진 폐혈관이 보이는가? 에 대해서 매우 그렇다 $12.5 \%$, 그렇다 $50 \%$, 보통이다 $25 \%$ 그렇지 않다. $12.5 \%$, 매우 그렇지 않다. $0 \%$ 이었다.

종격구조의 주행이 보이는가? 에 대해서 매우 그렇 다 $0 \%$, 그렇다 $25 \%$, 보통이다 $62.5 \%$ 그렇지 않다. $12.5 \%$, 매우 그렇지 않다. $0 \%$ 이었다.

좌측 횡격막 하부에 공기로 차있는 위장의 음영이 보이는가? 에 대해서 매우 그렇다 $25 \%$, 그렇다 $37.5 \%$, 보통이다 $12.5 \%$ 그렇지 않다. $25 \%$, 매우 그렇지 않다. $0 \%$ 이었다.

우측 횡격막 하부에 간에 의한 음영이 보이는가? 에 대해서 매우 그렇다 $0 \%$, 그렇다 $50 \%$, 보통이다 $25 \%$ 그 렇지 않다. $25 \%$, 매우 그렇지 않다. $0 \%$ 이었다..

\section{2) 숨을 내 쉰 후(expiration) X선을 조사시킨 영상}

견갑골은 가능한 한 폐야 밖으로 제거되어 있는가? 에 대해서 매우 그렇다 $37.5 \%$, 그렇다 $50 \%$, 보통이다 $12.5 \%$ 그렇지 않다. $0 \%$, 매우 그렇지 않다. $0 \%$ 이었다.

흥곽은 충분히 확장되어 있는가? 에 대해서 매우 그 렇다 $0 \%$, 그렇다 $37.5 \%$, 보통이다 $25 \%$ 그렇지 않다 $25 \%$, 매우 그렇지 않다. $12.5 \%$ 이었다.

영상의 대조도와 밀도는 충분한가? 에 대해서 매우 그렇다 $25 \%$, 그렇다 $50 \%$, 보통이다 $12.5 \%$ 그렇지 않 다. $12.5 \%$, 매우 그렇지 않다. $0 \%$ 이었다.

심장, 뼈, 횡격막, 폐의 marking은 선명한가? 에 대해 서 매우 그렇다 $25 \%$, 그렇다 $37.5 \%$, 보통이다 $25 \%$ 그렇 지 않다. $12.5 \%$, 매우 그렇지 않다. $0 \%$ 이었다.

골성흥곽과 폐경계가 뚜렷한가? 에 대해서 매우 그 렇다 $0 \%$, 그렇다 $75 \%$, 보통이다 $12.5 \%$ 그렇지 않 다. $12.5 \%$, 매우 그렇지 않다. $0 \%$ 이었다.

심장과 종격동에 의한 음영이 있는가? 에 대해서 매 우 그렇다 $0 \%$, 그렇다 $37.5 \%$, 보통이다 $50 \%$ 그렇지 않 다. $12.5 \%$, 매우 그렇지 않다. $0 \%$ 이었다.
Lung marking이 심장 뒤쪽으로 보이는가? 에 대해서 매우 그렇다 $0 \%$, 그렇다 $12.5 \%$, 보통이다 $62.5 \%$ 그렇지 않다. $25 \%$, 매우 그렇지 않다. $0 \%$ 이었다.

페문음영은 한 덩어리로 되지 않고 판독하기 쉬운 가? 에 대해서 매우 그렇다 $0 \%$, 그렇다 $37.5 \%$, 보통이 다 $37.5 \%$ 그렇지 않다. $12.5 \%$, 매우 그렇지 않다. $12.5 \%$ 이었다.

훙추의 추간판공간이 미세하게 보이는가? 에 대해서 매우 그렇다 $12.5 \%$, 그렇다 $62.5 \%$, 보통이다 $0 \%$ 그렇지 않다. $25 \%$, 매우 그렇지 않다. $0 \%$ 이었다.

기관과 좌우기관지의 투과상이 보이는가? 에 대해서 매우 그렇다 $0 \%$, 그렇다 $25 \%$, 보통이다 $37.5 \%$ 그렇지 않다. $25 \%$, 매우 그렇지 않다. $12.5 \%$ 이었다.

좌하행대동맥이 보이는가? 에 대해서 매우 그렇다 $0 \%$, 그렇다 $25 \%$, 보통이다 $37.5 \%$ 그렇지 않다. $25 \%$, 매 우 그렇지 않다. $12.5 \%$ 이었다.

심장과 횡격막으로 겹쳐진 폐혈관이 보이는가? 에 대 해서 매우 그렇다 $12.5 \%$, 그렇다 $37.5 \%$, 보통이다 $37.5 \%$ 그렇지 않다. $12.5 \%$, 매우 그렇지 않다. $0 \%$ 이었다.

종격구조의 주행이 보이는가? 에 대해서 매우 그렇 다 $0 \%$, 그렇다 $12.5 \%$, 보통이다 $62.5 \%$ 그렇지 않다. $25 \%$, 매우 그렇지 않다. $0 \%$ 이었다.

좌측 횡격막 하부에 공기로 차있는 위장의 음영이 보이는가? 에 대해서 매우 그렇다 $0 \%$, 그렇다 $37.5 \%$, 보통이다 $37.5 \%$ 그렇지 않다. $25 \%$, 매우 그렇지 않다. $0 \%$ 이었다.

우측 횡격막 하부에 간에 의한 음영이 보이는가? 에 대해서 매우 그렇다 $0 \%$, 그렇다 $50 \%$, 보통이다 $25 \%$ 그 렇지 않다. $25 \%$, 매우 그렇지 않다. $0 \%$ 이었다.

\section{3) 숨을 들이 마신 상태에서 흥부가 미세하게 움직 인 상태에서 $\mathrm{X}$ 선을 조사 시킨 영상}

견갑골은 가능한 한 폐야 밖으로 제거되어 있는가? 에 대해서 매우 그렇다 $25 \%$, 그렇다 $62.5 \%$, 보통이다 $12.5 \%$ 그렇지 않다. $0 \%$, 매우 그렇지 않다. $0 \%$ 이었다.

흥곽은 충분히 확장되어 있는가? 에 대해서 매우 그 렇다 $12.5 \%$, 그렇다 $37.5 \%$, 보통이다 $37.5 \%$ 그렇지 않다 $12.5 \%$, 매우 그렇지 않다. $0 \%$ 이었다. 
영상의 대조도와 밀도는 충분한가? 에 대해서 매우 그렇다 $12.5 \%$, 그렇다 $25 \%$, 보통이다 $25 \%$ 그렇지 않 다. $12.5 \%$, 매우 그렇지 않다. $0 \%$ 이었다.

심장, 뼈, 횡격막, 폐의 marking은 선명한가? 에 대해 서 매우 그렇다 $0 \%$, 그렇다 $12.5 \%$, 보통이다 $12.5 \%$ 그 렇지 않다. $37.5 \%$, 매우 그렇지 않다. $37.5 \%$ 이었다.

골성흉곽과 폐경계가 뚜렷한가? 에 대해서 매우 그 렇다 $0 \%$, 그렇다 $12.5 \%$, 보통이다 $25 \%$ 그렇지 않다. $40 \%$, 매우 그렇지 않다. $12.5 \%$ 이었다.

심장과 종격동에 의한 음영이 있는가? 에 대해서 매 우 그렇다 $0 \%$, 그렇다 $12.5 \%$, 보통이다 $62.5 \%$ 그렇지 않다. $25 \%$, 매우 그렇지 않다. $0 \%$ 이었다.

Lung marking이 심장 뒤쪽으로 보이는가? 에 대해서 매우 그렇다 $0 \%$, 그렇다 $0 \%$, 보통이다 $62.5 \%$ 그렇지 않다. $37.5 \%$, 매우 그렇지 않다. $0 \%$ 이었다.

페문음영은 한 덩어리로 되지 않고 판독하기 쉬운 가? 에 대해서 매우 그렇다 $0 \%$, 그렇다 $25 \%$, 보통이다 $0 \%$ 그렇지 않다. $50 \%$, 매우 그렇지 않다. $25 \%$ 이었다.

흥추의 추간판공간이 미세하게 보이는가? 에 대해서 매우 그렇다 $0 \%$, 그렇다 $50 \%$, 보통이다 $12.5 \%$ 그렇지 않다. $37.5 \%$, 매우 그렇지 않다. $0 \%$ 이었다.

기관과 좌우기관지의 투과상이 보이는가? 에 대해서 매우 그렇다 $0 \%$, 그렇다 $0 \%$, 보통이다 $75 \%$ 그렇지 않 다. $25 \%$, 매우 그렇지 않다. $0 \%$ 이었다.

좌하행대동맥이 보이는가? 에 대해서 매우 그렇다 $0 \%$, 그렇다 $12.5 \%$, 보통이다 $25 \%$ 그렇지 않다. $62.5 \%$, 매우 그렇지 않다. $0 \%$ 이었다.

심장과 횡격막으로 겹쳐진 폐혈관이 보이는가? 에 대해서 매우 그렇다 $0 \%$, 그렇다 $0 \%$, 보통이다 $12.5 \%$ 그렇지 않다. $50 \%$, 매우 그렇지 않다. $37.5 \%$ 이었다.

종격구조의 주행이 보이는가? 에 대해서 매우 그렇 다 $0 \%$, 그렇다 $0 \%$, 보통이다 $50 \%$ 그렇지 않다. $50 \%$, 매 우 그렇지 않다. $0 \%$ 이었다.

좌측 횡격막 하부에 공기로 차있는 위장의 음영이 보이는가? 에 대해서 매우 그렇다 $0 \%$, 그렇다 $37.5 \%$, 보통이다 $25 \%$ 그렇지 않다. $25 \%$, 매우 그렇지 않다. $12.5 \%$ 이었다.
우측 횡격막 하부에 간에 의한 음영이 보이는가? 에 대해서 매우 그렇다 $0 \%$, 그렇다 $50 \%$, 보통이다 $25 \%$ 그 렇지 않다. $12.5 \%$, 매우 그렇지 않다. $12.5 \%$ 이었다.

\section{2. 누운 자세 복부 전후 방향 $\mathrm{X}$ 선 검사 영상 (Fig. 4)평가 결과}

\section{1) 숨을 내 쉰 후(expiration) X선을 조사시킨 영상}

복강내 장기의 전반적인 윤곽 구분이 되는가? 에 대 해서 매우 그렇다 $12.5 \%$, 그렇다 $75 \%$, 보통이다 $12.5 \%$ 그렇지 않다. $0 \%$, 매우 그렇지 않다. $0 \%$ 이었다.

영상의 대조도는 선명한가? 에 대해서 매우 그렇다 $37.5 \%$, 그렇다 $62.5 \%$, 보통이다 $0 \%$ 그렇지 않다. $0 \%$, 매 우 그렇지 않다. $0 \%$ 이었다.

장요근이 보이는가? 에 대해서 매우 그렇다 $12.5 \%$, 그렇다 $50 \%$, 보통이다 $25 \%$ 그렇지 않다. $12.5 \%$, 매우 그렇지 않다. $0 \%$ 이었다.

가스 음영이 식별되는가? 에 대해서 매우 그렇다 $37.5 \%$, 그렇다 $25 \%$, 보통이다 $25 \%$ 그렇지 않다. $12.5 \%$, 매우 그렇지 않다. $0 \%$ 이었다.

간, 콩팥의 윤곽을 식별할 수 있는가? 에 대해서 매 우 그렇다 $12.5 \%$, 그렇다 $37.5 \%$, 보통이다 $25 \%$ 그렇지 않다. $25 \%$, 매우 그렇지 않다. $0 \%$ 이었다.

외복벽과 복막의 지방층이 보이는가? 에 대해서 매 우 그렇다 $37.5 \%$, 그렇다 $25 \%$, 보통이다 $37.5 \%$ 그렇지 않다. $0 \%$, 매우 그렇지 않다. $0 \%$ 이었다.

colon의 주행을 확인할 수 있는가? 에 대해서 매우 그렇다 $12.5 \%$, 그렇다 $50 \%$, 보통이다 $0 \%$ 그렇지 않다. $25 \%$, 매우 그렇지 않다. $12.5 \%$ 이었다.

전체적인 장내의 가스분포를 파악할 수 있는가? 에 대해서 매우 그렇다 $0 \%$, 그렇다 $87.5 \%$, 보통이다 $12.5 \%$ 그렇지 않다. $0 \%$, 매우 그렇지 않다. $0 \%$ 이었다.

척추 및 횡돌기의 윤곽이 잘 보이는가? 에 대해서 매우 그렇다 $37.5 \%$, 그렇다 $62.5 \%$, 보통이다 $0 \%$ 그렇지 않다. $0 \%$, 매우 그렇지 않다. $0 \%$ 이었다.

복강내 장기의 겹침을 확인할 수 있는가? 에 대해서 매우 그렇다 $0 \%$, 그렇다 $50 \%$, 보통이다 $37.5 \%$ 그렇지 
않다. $12.5 \%$, 매우 그렇지 않다. $0 \%$ 이었다.

\section{2) 숨을 들이 마신 후(inspiration) $X$ 선을 조사시킨 영상}

복강내 장기의 전반적인 윤곽 구분이 되는가? 에 대 해서 매우 그렇다 $0 \%$, 그렇다 $62.5 \%$, 보통이다 $12.5 \%$ 그렇지 않다. $25 \%$, 매우 그렇지 않다. $0 \%$ 이었다.

영상의 대조도는 선명한가? 에 대해서 매우 그렇다 $25 \%$, 그렇다 $62.5 \%$, 보통이다 $0 \%$ 그렇지 않다. $12.5 \%$, 매우 그렇지 않다. $0 \%$ 이었다.

장요근이 보이는가? 에 대해서 매우 그렇다 $0 \%$, 그 렇다 $37.5 \%$, 보통이다 $37.5 \%$ 그렇지 않다. $25 \%$, 매우 그 렇지 않다. $0 \%$ 이었다.

가스 음영이 식별되는가? 에 대해서 매우 그렇다 $37.5 \%$, 그렇다 $50 \%$, 보통이다 $12.5 \%$ 그렇지 않다. $0 \%$, 매우 그렇지 않다. $0 \%$ 이었다.

간, 콩팥의 윤곽을 식별할 수 있는가? 에 대해서 매 우 그렇다 $25 \%$, 그렇다 $37.5 \%$, 보통이다 $0 \%$ 그렇지 않 다. $37.5 \%$, 매우 그렇지 않다. $0 \%$ 이었다.

외복벽과 복막의 지방층이 보이는가? 에 대해서 매 우 그렇다 $37.5 \%$, 그렇다 $12.5 \%$, 보통이다 $25 \%$ 그렇지 않다. $25 \%$, 매우 그렇지 않다. $0 \%$ 이었다.

colon의 주행을 확인할 수 있는가? 에 대해서 매우 그렇다 $12.5 \%$, 그렇다 $37.5 \%$, 보통이다 $0 \%$ 그렇지 않다. $50 \%$, 매우 그렇지 않다. $0 \%$ 이었다.

전체적인 장내의 가스분포를 파악할 수 있는가? 에 대해서 매우 그렇다 $25 \%$, 그렇다 $37.5 \%$, 보통이다 $37.5 \%$ 그렇지 않다. $0 \%$, 매우 그렇지 않다. $0 \%$ 이었다.

척추 및 횡돌기의 윤곽이 잘 보이는가? 에 대해서 매우 그렇다 $25 \%$, 그렇다 $62.5 \%$, 보통이다 $12.5 \%$ 그렇 지 않다. $0 \%$, 매우 그렇지 않다. $0 \%$ 이었다.

복강내 장기의 겹침을 확인할 수 있는가? 에 대해서 매우 그렇다 $12.5 \%$, 그렇다 $12.5 \%$, 보통이다 $50 \%$ 그렇 지 않다. $25 \%$, 매우 그렇지 않다. $0 \%$ 이었다.

\section{3) 숨을 쉬고 있는 상태에서 $\mathrm{X}$ 선을 조사시킨 영상}

복강내 장기의 전반적인 윤곽 구분이 되는가? 에
대해서 매우 그렇다 $0 \%$, 그렇다 $12.5 \%$, 보통이다 $25 \%$ 그렇지 않다. $50 \%$, 매우 그렇지 않다. $12.5 \%$ 이었다.

영상의 대조도는 선명한가? 에 대해서 매우 그렇다 $0 \%$, 그렇다 $37.5 \%$, 보통이다 $37.5 \%$ 그렇지 않다. $12.5 \%$, 매우 그렇지 않다. $12.5 \%$ 이었다.

장요근이 보이는가? 에 대해서 매우 그렇다 $0 \%$, 그 렇다 $12.5 \%$, 보통이다 $50 \%$ 그렇지 않다. $25 \%$, 매우 그 렇지 않다. $12.5 \%$ 이었다.

가스 음영이 식별되는가? 에 대해서 매우 그렇다 $0 \%$, 그렇다 $37.5 \%$, 보통이다 $25 \%$ 그렇지 않다. $37.50 \%$, 매우 그렇지 않다. $0 \%$ 이었다.

간, 콩팥의 윤곽을 식별할 수 있는가? 에 대해서 매 우 그렇다 $0 \%$, 그렇다 $12.5 \%$, 보통이다 $0 \%$ 그렇지 않 다. $75 \%$, 매우 그렇지 않다. $12.5 \%$ 이었다.

외복벽과 복막의 지방층이 보이는가? 에 대해서 매 우 그렇다 $0 \%$, 그렇다 $12.5 \%$, 보통이다 $50 \%$ 그렇지 않 다. $37.5 \%$, 매우 그렇지 않다. $0 \%$ 이었다.

colon의 주행을 확인할 수 있는가? 에 대해서 매우 그렇다 $0 \%$, 그렇다 $0 \%$, 보통이다 $50 \%$ 그렇지 않다. $37.5 \%$, 매우 그렇지 않다. $12.5 \%$ 이었다.

전체적인 장내의 가스분포를 파악할 수 있는가? 에 대해서 매우 그렇다 $0 \%$, 그렇다 $50 \%$, 보통이다 $25 \%$ 그 렇지 않다. $25 \%$, 매우 그렇지 않다. $0 \%$ 이었다.

척추 및 횡돌기의 윤곽이 잘 보이는가? 에 대해서 매우 그렇다 $25 \%$, 그렇다 $50 \%$, 보통이다 $12.5 \%$ 그렇지 않다. $12.5 \%$, 매우 그렇지 않다. $0 \%$ 이었다.

복강내 장기의 겹침을 확인할 수 있는가? 에 대해서 매우 그렇다 $0 \%$, 그렇다 $12.5 \%$, 보통이다 $37.5 \%$ 그렇지 않다. $25 \%$, 매우 그렇지 않다. $25 \%$ 이었다.

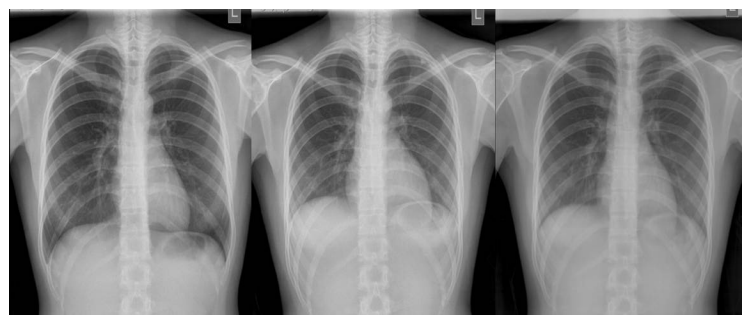

Fig. 3. Radiographic image for the Chest PA X-ray (Lt.; inspiration. Median; expiration, Rt.; breathing) 


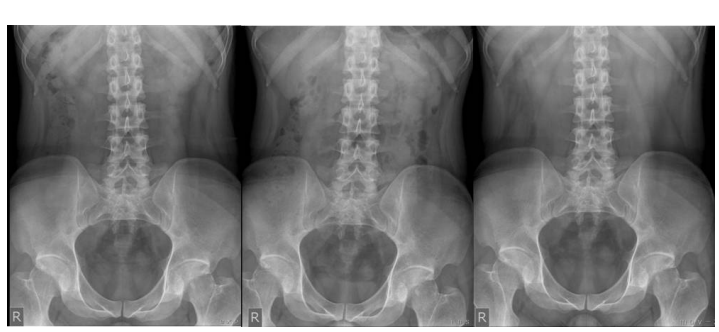

Fig. 4. Radiographic image for the supine abdomen AP X-ray (Lt.; inspiration. Median; expiration, Rt.; breathing)

\section{3. 자료에 대한 통계분석}

본 연구에 참여한 표본의 수가 너무 적어 정규분포 임을 확인하는 것이 불가능했다. 그리하여 적합성 시험 을 Kolmogorov-Smirnov test을 통해 진행하였고 정규분 포임을 확인하였다. 그리고 그 결과에 대한 유의성 검 정은 One-way ANOVA를 이용하였고 두 그룹에서 유의 한 차이가 있었다 $(\mathrm{p}<0.001)$.

\section{$\mathrm{IV}$. 고찰}

가장 좋은 $\mathrm{X}$ 선 사진을 만들고 그 사진을 정확하게 독영하여 정확한 진단으로 치료에 이어 지는 것이 양 질의 의료라 하겠다. 이에 따라 의료내용의 품질보장 (MTQA, Medical Total Quality Assurance)과 의료 기술의 사전평가(MTA, Medical Technology Assesment)의 이행이 시급한 과제로 대두되고 있다. 흥, 복부X선 사진의 평 가에서도 환자에 대해서 의료의 질을 종합적으로 보장 하는 MTQA는 병원에서 의사를 포함하여 전체 의료 기술자의 품질이 언제든지 보증되어 있어야 한다. 이것 을 실현시키기 위해서는 각 의료기관 단위나 각 의료 기술자 개개인에 대한 의료기술의 평가는 필수 요건이 라 하겠다. 우리나라에서도 병원에 대한 평가가 이루어 져 환자 서비스에 대해서 문제 제기가 이루어지는 시 대로 대두되고 있다. MTQA나 MTA를 실현하기 위해 서는 의료기술의 안전성과 유효성 등을 의학 측면에서 평가하여 효율이나 비용의 연관을 분석하는 의료경제 의 면에서 평가하고 또 사회나 윤리면 에서의 영향이 나 연관 등 다면적인 시야에서 종합적으로 사전평가 또는 재평가를 할 필요가 있다. 현재 흥, 복부 $\mathrm{X}$ 선 사 진의 화질을 평가하는 방법으로는 평가표가 이용되고
있다. 평가표에 대해서는 미국의 George Washington대 학에서 필름-증감지의 연결의 평가에 이용된 J.J.Vuvich(B R H)의 평가표, Greenfield, 藤原, 吉田의 체 크포인트등과 일본 결핵예방협회법등이 있으나 실제로 체크하는 사람의 Eye - Brain - System에 따르는 것이 현 실적으로 사람이 평가하는 것에 대해서 심리적 영향이 크게 미치게 되기에 될 수 있으면 객관적인 평가로 대 치해야 할 필요성이 대두되고 있다. 일반적으로 X선 영 상의 형성과 평가과정은 아래의 (Table 3)과 같다.

Table 3. Evaluation process for the radiographic image

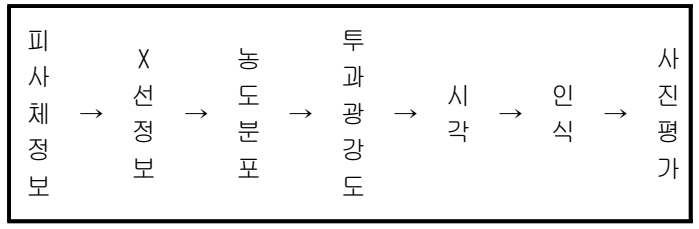

여기에서, 피사체 정보는 피사체 특징의 파악과 오 리엔테이션, 위치 잡이. X선 정보는 $\mathrm{X}$ 선 장치(출력, 안정성, 재현성), 증감지, 격자 등의 요소. 농도분포는 자동현상기 처리 특성(안정성, 재현성), 처리액 보충량, 농도. 투과광 강도는 관찰 등 의 밝기, 밝기의 균등성, 관찰실의 밝기. 시각, 인식은 의학적 지식, $\mathrm{X}$ 선 해부학, 경험, 감각 등이 관여하는 과정으로 이루어진다. 여기 에서 시각, 인식의 과정은 개인적 차이가 있다. 따라서 사진 평가는 객관성이 있게 하기 위해서 다양한 case의 영상으로 사진의 대한 세미나 등 정보 교환의 장에 적 극적으로 참가하여 자기 연마를 해야 한다[6-7]. 이와 같은 기능을 의식적으로 하지 않으면 기술은 저하되고 이를 철저히 실시하면 그 파급효과로서 병원 상호간의 기술적 균등화가 되고 동일 환자를 병원마다 촬영하여 중복 촬영이 되는 것을 방지하고 피폭 선량의 경감에 이어지게 된다. 이를 달성하기 위해서는 각 계통의 Parameter를 잘 정리하여 과정 전체의 최적화, 정당화를 도모하는 TQC(Total Quality Control)나 표준화는 중요한 과제이다. 이번 연구에서도 동일한 영상임에도 불구하 고 사진을 평가하는 사람이 누구냐에 따라 다양한 평 가가 이루어 진 것을 알 수 있었으나 선 자세 흥부 후 전방향 X선 검사 영상의 경우 숨을 들이 마신 후 (inspiration) X선을 조사시킨 영상의 평가 결과가 가장 좋은 영상으로 평가되었고, 누운 자세 복부 전후방향 $\mathrm{X}$ 
선 검사 영상평가의 경우도 숨을 내 쉰 후(expiration) X 선을 조사시킨 영상의 평가결과가 가장 좋은 영상으로 평가되어 이론으로 알고 있었던 내용을 확인할 수 있 었다. 또한 X선을 조사 시키는 도중에 환자의 미세한 움직임이나 호흡 등이 불안정할 경우 영상에서의 불선 예도를 확인할 수 있었다. 본 연구를 통해 일반 X선 검사에서 가장 기본이 되는 검사 시 환자 호흡, 움직임 등에 의한 영상에서의 불선예도에의 중요성을 다시 한 번 확인 할 수 있었고 제한점으로는 표본의 수 가 충분 하지 못해 향후 표본의 수가 충분한 연구가 진행되기 를 바란다.

\section{V. 결론}

흥, 복부 $\mathrm{X}$ 선 검사 시 각 검사 별 평가항목(Table 1 , Table 2)에 대해 호흡의 변화에 따른 영상에서 일반적 으로 잘 알려진 바와 같이 흥부X선 검사의 경우 평가 항목 모두에서 호흡을 들이마신 상태에서 검사한 영상 이 가장 우수한 영상임을 확인 하였고, 복부X선 검사의 경우 호흡을 내쉰 후 정지한 상태에서 검사한 영상이 가장 우수한 영상임을 확인 하였다. 또한 흥, 복부 X선 영상 검사 시 각 검사 부위 별 가능한 많은 양의 정보 가 포함되어있는 영상을 만들어 주기 위해서 X선 조사 중 수의 적 또는 불수의 적 운동에 의한 영향을 받지 않게 환자를 최대한 편안한 환경에서 검사가 진행될 수 있도록 해야 하고, 장비의 부하가 걸리지 않는 한 X 선 조사시간을 짧게 설정해야 한다. 호흡 또한 목적하 는 대상 부위가 어디인가에 따라 대상 장기 부위가 가 능한 넓게 보일 수 있도록 조절한 상태에서 검사가 진 행되어야 함을 확인할 수 있었다.

\section{참고문헌}

[1] National Council on Radiation Protection and Measurements: NCRP Report No. 93, 1988.

[2] http://www.nrc.gov/reading-rm/basic-ref/ glossary/exposure.html

[3] 강해원, 박준철, 강홍석, 이인자, 신화수, 허준. 흉부 $\mathrm{X}$ 선 사진 시스템의 성능평가, 대한방사선기술학회지(방사선기술과학), Vol.10, No.1, pp.31-35, 1987.

[4] 조평곤, 강병삼, 김승철 등. 방사선영상학 개정3판, pp.446-449, 대학서림, 2012.
[5] 조평곤, 강병삼, 김승철 등. 방사선영상학 개정3판, pp.240-243, 대학서림, 2012.

[6] 이기열, 강덕식, 강은영 등. 흉부영상진단 $\mathrm{X}$ 선, pp.1-22, 군자출판사, 2012

[7] 가톨릭대학교 의과대학 방사선학교실, 실전 영상의학, pp.29-31, 군자출판사, 2010. 